\section{ECONOMICS}

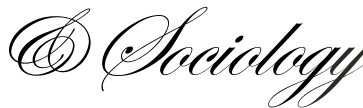

\title{
FOOD AND BEVERAGE BRAND DEVELOPMENT: GLOBAL TRENDS AND DIRECTIONS FOR UKRAINE
}

\begin{abstract}
The article presents the results of research on the development of international and Ukrainian brands, and also analyzes food and beverages brands position in the Interbrand rankings and UkrBrand. Moreover, the research studies the dynamics of their value and the representation of world's leading brands on the Ukrainian market in order to identify global trends and characteristics of development in Ukraine.
\end{abstract}

789X.2014/7-2/12

JEL Classification: L66, P2

Keywords: brand, brand valuation, rating, Interbrand, UkrBrand.

\section{Introduction}

Food industry is the most important part of production. It is designed to ensure national food sovereignty and food security. Understanding the specific role of brands in business management helps to transform the knowledge into an effective tool that facilitates maintaining competitive position on the market and relationship with the consumer.

The research contributed greatly to the theory of brand management, studies of definitions the terms: "brand" and "brand name", and also helped addressing questions regarding their development in the scientific heritage of the founders of marketing D. Aaker, T. Gad, F. Kotler (2003, 2001, 2008). Theoretical and practical principles of branding are set forth in the works of Russian scientists including: V. Domnin (Domnin, 2004). Among the scientific works which studied the problem of brand management there are works of Ukrainian authors, like: O. Shafalyuk, O. Zozuliov (2009, 2010).

Brand development is influenced by global imperatives, but has characteristic features of the Ukrainian economy. The main objective of this paper is to determine these features.

In contrast to international practice in Ukrainian science the term "brand" appeared in the late twentieth century. The emergence and development of brands in Ukraine were possible thanks to gaining independence of the country. This changed the economic model of development, the use of enterprise management and marketing tools, and developed new consumer behaviour. The present Ukrainian food market is characterized by fierce competition between different manufacturers and their brands, which we think is a marketing tool - the source of competitive advantage that determines the strategic direction, forms and maintains relationships with customers. 


\section{Brands - world leaders}

Among the brands represented in Ukraine by manufacturing facilities or subsidiaries, one should mention: the global Coca-Cola, Pepsi, Nestlé, Nescafe, DANONE. They are the leaders of the most prestigious annual ranking formed by experts of Interbrand, which has operated on the market since 1974, and according to the information from the company's website "since the time when the world began to realize that the brand is not just a word or a logo". The branches of the company operate in 29 countries under the following slogan: "We create brand value and manage it". Interbrand calculates the share of the profits, which the company gains by brand, its role in intangible assets, and the brand's power. Interbrand annual published the results of their research. The research identified the presence of the leading food industry representatives from among a 100 of the world's leading brands (Table 1).

An analysis of the Interbrand's survey results, conducted in 2011 among 100 world leaders, proves the presence of 15 brands of food, including 4 soft drinks brands, 7 alcohol and 4 facilitate food choices. In terms of the country of origins of the aforementioned brands, traditionally, the leader's position is occupied by the United States: 49 positions among top 100,10 positions in the top ten, seven of the 15 best brands of food and beverages. Second place - Germany: 10 representatives among a hundred of the world's leading producers, but no food brands. The fight for third place in the ranking takes place between France and Japan, both of which was rated to have 7 participants, but 2 of the 15 food brands are French.

Table 1. Ranking of leading brands - by Interbrand

\begin{tabular}{lccccccc}
\hline \multirow{2}{*}{ Brand } & \multirow{2}{*}{$\begin{array}{c}\text { Country of } \\
\text { origin }\end{array}$} & Sphere & \multicolumn{5}{c}{ Period } \\
\cline { 4 - 8 } & & & 2007 & 2008 & 2009 & 2010 & 2011 \\
\cline { 4 - 8 } Coca Cola & USA & Soft drinks & 1 & 1 & 1 & 1 & 1 \\
\hline Pepsi & USA & Soft drinks & 26 & 26 & 23 & 23 & 23 \\
\hline Budweiser & USA & Alcohol & 30 & 33 & 30 & 30 & 29 \\
\hline Nescafe & Switzerland & Drinks & 24 & 28 & 25 & 27 & 30 \\
\hline Kellogg's & USA & Food & 40 & 39 & 34 & 35 & 34 \\
\hline Heinz & USA & Food & 53 & 56 & 48 & 46 & 49 \\
\hline Wrigley & USA & Food & 59 & 61 & 51 & - & - \\
\hline Danone & France & Food & 67 & 66 & 60 & 58 & 52 \\
\hline Nestle & Switzerland & Food & 63 & 63 & 58 & 57 & 55 \\
\hline Sprite & USA & Soft drinks & - & - & - & 61 & 63 \\
\hline Moet \& Chandom & France & Alcohol & 85 & 83 & 82 & 79 & 77 \\
\hline Jack Daniels & USA & Alcohol & - & - & - & 78 & 78 \\
\hline Hennessy & France & Alcohol & 87 & 95 & - & - & - \\
\hline Corona & Mexico & Alcohol & - & - & - & 85 & 86 \\
\hline Johnnie Walker & Great Britain & Alcohol & - & - & - & 92 & 88 \\
\hline Smirnoff & Great Britain & Alcohol & - & - & 84 & 89 & 89 \\
\hline Heineken & Great Britain & Alcohol & - & - & - & 93 & 91 \\
\hline
\end{tabular}

Source: data based on Interbrand.

Particular attention should be paid to the result of Great Britain and Switzerland, which are countries of origin for respectively 5 and 4 brands out of the best hundred, and each are represented by two of the leading brands of drinks and food. As a result of 2010, new beer brands strengthened their position in 2011: Mexican Corona and Dutch Heineken. Value parameters of global brands are presented in Table 2. 
The undisputed leader in value with a considerable margin is Coca Cola; the second leading segment of the food and beverage is taken by Pepsi for several years. Third place (according to Interbrand) - producer of alcoholic drinks Budweiser, fourth position is Nescafe, the top five ends with Kellogg's the following places were taken by Heinz, Danone, Nestle, Sprite and others.

The strong growth of the brand during the period is demonstrated by Coca Cola, Pepsi, Danone, Nestle. Downward dynamics is characteristic for Nescafe in 2010 and 2011. Sprite also worsened its performance in 2011, compared to the previous year, when it only entered the top hundred of the world's most expensive brands.

Table 2. Leading manufacturers of food and beverages rated by Interbrand according to their value (in 1 billion USD)

\begin{tabular}{|c|c|c|c|c|c|c|c|}
\hline \multirow{2}{*}{ Brand } & \multicolumn{4}{|c|}{ Value } & \multicolumn{3}{|c|}{ Growth } \\
\hline & 2008 & 2009 & 2010 & 2011 & 09/08, \% & $10 / 09, \%$ & $11 / 10, \%$ \\
\hline Coca Cola & 66,667 & 68,734 & 70,452 & 71,861 & 3 & 2 & 2 \\
\hline Pepsi & 13,249 & 13,706 & 14,061 & 14,590 & 3 & 3 & 4 \\
\hline Budweiser & 11,438 & 11,833 & 12,252 & 12,252 & 3 & 4 & 0 \\
\hline Nescafe & 13,056 & 13,317 & 12,753 & 12,115 & 2 & -4 & -5 \\
\hline Kellogg's & 9,710 & 10,428 & 11,041 & 11,372 & 7 & 6 & 3 \\
\hline Heinz & 6,646 & 7,244 & 7,534 & 7,609 & 9 & 4 & 1 \\
\hline Wrigley & 6,105 & 6,731 & - & - & 10 & - & - \\
\hline Danone & 5,408 & 5,960 & 6,363 & 6,936 & 10 & 7 & 9 \\
\hline Nestle & 5,592 & 6,319 & 6,548 & 6,613 & 13 & 4 & 1 \\
\hline Sprite & - & - & 5,777 & 5,604 & & - & -3 \\
\hline Moet \& Chandom & 3,951 & 3,754 & 4,021 & 4,383 & -5 & 7 & 9 \\
\hline Jack Daniels & - & - & 4,036 & 4,319 & & - & 7 \\
\hline Hennessy & 3,513 & & & & & & \\
\hline Corona & & & 3,847 & 3,924 & & - & 2 \\
\hline Johnnie Walker & - & - & 3,557 & 3,842 & & - & 8 \\
\hline Smirnoff & - & 3,698 & 3,624 & 3,841 & - & -2 & 6 \\
\hline Heineken & - & - & 3,516 & 3,809 & & - & 8 \\
\hline
\end{tabular}

Source: prepared by the author based on Interbrand.

It should be noted that none of the Ukrainian brands are represented in the global rankings in 2011, however consumers are familiar with the world's leading brands and some of their products are manufactured in Ukraine.

Let us now analyze the experience of global companies and features of branding on the Ukrainian market.

Interbrand's rankings' leader, Coca Cola, occupied the first place12 times, the results of 2011 brand evaluation amounted to 71.861 billion U.S. dollars. Coca Cola manufacures its products in over 800 plants in more than 200 countries worldwide. Expansion of Coca-Cola on the Ukrainian market began with the opening of its offices in 1992. The next step was the opening of the plant in 1994 in Ukraine, and in 1998 the manufacturing plant in Brovary started working at full capacity. In 2008 "Coca-Cola Ukraine" bought a brand of kvass sourced from natural fermentation, "Yarylo". "Coca-Cola Beverages Ukraine" produces, sells and carries out distribution of carbonated water, energy drinks, iced tea and juices. In addition to the leader, Coca Cola, among the global brands of soft drinks, there are Sprite (63 place in Interbrand's ranking 2011), Fanta, Schweppes; local juices like Rich, BotaniQ and Dobryy; drinking water BonAqua etc. 
Third year in a row Pepsi has taken the $23^{\text {rd }}$ position among the world's most expensive brands, and second in the category of soft drinks. It is owned by PepsiCo International Holding that is represented in over 200 countries around the world. Its assortment portfolio covers 22 areas of product lines, including: juices, carbonated beverage, healthy eating, sports nutrition, chips and others. The global portfolio of brands is represented by Pepsi, Lipton, Tropicana, 7 up and Lays.

In 2007, PepsiCo invested about 100 million U.S. dollars in the company called "Sandora", and in 2009 it began production of PepsiCo beverage portfolio in "Sandora" factories. By 2011 PepsiCo was the leader on the Ukrainian juice market with the share of 47\%. Production facilities in Ukraine include PepsiCo's plant involved with processing fruits, vegetables and juices in the Mykolaiv region, the plant producing carbonated drinks and iced tea in the Mykolaiv region, and the facility processing fruits and vegetables in the Kherson region.

Among the promising strategic directions of PepsiCo's development on the European market there is a share repurchase of "Wimm-Bill-Dann Ukraine" ("WBD"), and solidifying its position in the market of juices and dairy products. The strategy of "WBD" (which was created in Russia in 1992) is to produce dairy products in the region where they are consumed. The company consists of 37 enterprises, 3 of which are located on the territory of Ukraine: Kyivskiy Milk Plant № 3 - since 2000, Burynskiy plant of dry milk and Kharkiv Dairy Plant - since 2002.

Ukrainian portfolio consists of "Slov'yanochka", "Veselyy molochnyk", "Domik v derebnie", "Chodo", "Ryzhyy Up", "Fruhurt", "Mazhytel", "NEO, NeoVit", "Romol", "Agusha". There also are Russian "WBD" brands at the Ukrainian market: "Lamber", "Liubimyy sad", "Chudo-Yagoda", "Yessentuki".

Nestlé, the largest food manufacturer in the world and owner of one of the most expensive brands, is represented today by 511 factories in 86 countries, employing 265,000 people. Its products are sold in 120 countries. According to the website of the company, Nestle started its operations in Ukraine in 1994 with the opening of a branch in the country and starting the promotion of international brands Nescafé, Nesquik, Nuts, KitKat and others on the Ukrainian market.

In 1998 Nestlé S.A. strengthened its position in the Ukrainian market through the purchase of a controlling share in JSC "Lviv Confectionery factory "Svitoch". In 2003 for the purpose of business and the development of distribution network "Nestle Ukraine" Ltd. was opened in Kiev. That same year, the company diversified activities through the purchase of $100 \%$ of the shares of "Volynholdinh" and became the owner of TM "Torchyn".

Since 2009 the factory "Svitoch" in Lviv introduced a production line of coffee drinks under the brand Nescafe that, according to the results of Interbrand, ranks 30th place in the world's rankings. In 2010 Nestlé purchased "Tekhnokom" Ltd - producer of instant food products under the "MIVINA" trademark.

"Nestlé Ukraine" is growing rapidly, as proven by its total sales of 3,122 billion UA hryvnyas in 2009 , which was an increase of $16 \%$ when compared to the previous period. In 2010 the company's enterprises increased their sales by $30.5 \%$ compared to 2009 , and achieved the total sales of 4.016 billion UA hryvnyas. The total investment amounted $64 \mathrm{~m}$ UA hryvnyas. Total sales of "Nestle" in the Ukrainian market in 2011 reached 4.66 billion UA hryvnyas, an increase to the previous year is $23 \%$. Investments in modernization and expansion of production at factories in Ukraine amounted to $126 \mathrm{~m}$ UA hryvnyas. Among the prospective acquisitions there is also an American company «Pfizer».

One of the winners of the "Interbrand" rating in the category of food for many years had been Danone with the value of 6839 billion US dollars, finishing at 52 place in 2011.

Brand name of Danone is derived from the abbreviated name "Daniel", the name of the son of the brand's founder and one of the first customers of manufactured yoghurts, which were 
distributed through pharmacies since 1919. In 2010 the French Danone, which unites 160 plants in the world, commenced the merging of the Russian "Yunimilk" that enabled Danone become the largest milk producer in Ukraine and Russia. In Ukraine the following plants belong to "Yunimilk-Danon": "Danone-Dnipro" (Kherson), "Galakton" (Kyiv), "Kremez" (Kremenchuh).

Ukrainian consumers are familiar with brands producing high-quality dairy products like "Rastishka", "Danissimo", "Activia», «Actimel», «Zhyvynka", "Veselyi pastushok", "Biobalans", "Prostokvashino", "Tema", "Galakton".

Among the ranking's leaders that do not have production facilities in Ukraine, but are well known to consumers, are Heinz, Smirnoff and Heineken.

According to an evaluation made in 2011 Heinz occupies the 49 position among the most valuable brands in the world. Based in the United States, global sustainable development program allowed Heinz to base production in 26 countries on 6 continents. Ukrainian consumer products under the brand Heinz are made in Poland and Russia.

A new brand of 2009, Smirnoff, founded by a Russian merchant Peter Smirnov in Moscow in 1860, belongs to one of the companies in Great Britain. According to 2011 ranking brand value reached 3.841 billion US dollars, which showed $6 \%$ increase in value compared to 2010.

In spite of the fact that it is produced only at 7 corporation breweries in Mexico, the Mexican Corona, founded in 1925, is sold in 150 countries on 5 continents. It holds the largest market share among imported beers on 20 national markets. In 2010 it joined the hundred of most expensive brands in the world; and in 2011 Interbrand estimated its value as 3.924 billion dollars, corresponding to the 86 position.

Fresh to the Interbrand ranking of 2010 Heineken began its history in the Netherlands in 1864. Today it is a corporate brand of the company that produces beer for 125 breweries in 71 countries on 5 continents. Under the slogan "Discover the World" it offers its products in 178 countries. The rapid success of the years 2006-2011 is explained by contracts signed with countries with large markets (Russia - 2006, Mexico and Brazil - 2010, Nigeria, Ethiopia 2011). Ukrainian consumers are offered Heineken's beer, brewed in Russia.

It is worth to note that among the brands that are not included in the Interbrand's ranking, there is an international company called Kraft Foods, which belongs to the country's manufacturing facilities or subsidiaries. It is one of the leaders of the Ukrainian market and world's second largest food producer with an annual turnover of about 40 billion US dollars, 6.8 billion of which are accounted for dairy products. Kraft Foods was founded in 1903 (in the U.S.), now it sells its products in 155 countries. In Ukraine, the company is represented in terms of coffee and coffee drinks of Jacobs (1895, Germany) since 1998 and Carte Noire (1978, France), in 2003 in the category of confectionery brands Milka and Korona, biscuit segment "Teddy Barney" and the chips production of brand "Lux".

One of the players of the Ukrainian beer market and the soft drinks market is "Slavutych Carlsberg Group", founded in 1996 on the foundations of Zaporizhzhya brewery № 2 (built in 1974); today it has factories in Kiev and Lviv. The portfolio of brands is represented by the following beers: "Slavutych", "Slavutych ICE", "Lviv", "Arsenal", "Khmilne" and soft drinks "Kvas Taras" and "Top Tea".

Other strong global companies also successfully operate on the Ukrainian market. That includes:

- oil and fat industry - «Bunge» corporation founded in 1818 in Amsterdam with headquarters in the U.S. and is represented by 450 companies in 30 countries. It is known in Ukraine under the brand name "Oleyna";

- the French dairy industry, "Lactalis Group" (founded in 1933, under the brand with a worldwide reputation - Président sells every hour about 50,000 products in 170 countries), is represented in Ukraine by Mykolayiv and Pavlograd dairy plants. These 
manufacture products under the names: "Fanny", "Laktoniya", "Bilosvit", "Immuno+", "Dolce", "President";

- the world famous «Dragon Capital» and «East Capital Bering Ukraine Fund» that produce ketchups, sauces and tomato paste under the brand name "Chumak", which is perceived by domestic consumers as a purely Ukrainian make;

- the beer company, SUN InBev Ukraine (established in 2008 as a result of close cooperation of Belgian-Brazilian InBev and American Anheuser-Busch) Three Ukrainian breweries belong to the company - Chernihiv "Desna" (1996), Mykolayiv "Amber" (1999), Kharkiv "Rohan"; in the brand portfolio of SUN InBev Ukraine "Chernihiv", "Rogan", "Yantar".

\section{National brands}

For the companies-producers the most difficult issue of branding is a problem of estimation of the brand's value due to lack of a common methodology. It should be noted that it is difficult to assess value of brands in Ukrainde due to a varied professional assessment of the. It is important to remember, however, the importance of the annual contests "Brand of the Year", "Choice of the Year" and "Best brand of the year". It is worth to mention UkrBrand agency, which is ranking top national brands, identifying 50 most expensive ones since 2006, and 100 most expensive brands since 2010 (Table 3). Similarly important are the results of a study done by "Halytski kontrakty", which has been implementing the project "Gvardiya" Corporate Brand ranking" since 2004.

Table 3. National brand ranking UkrBrand, 2008-2011

\begin{tabular}{llcccc}
\hline \multirow{2}{*}{ Brand } & \multirow{2}{*}{ Type of production } & \multicolumn{4}{c}{ Period } \\
\cline { 3 - 6 } & & \multicolumn{1}{c}{2008} & 2009 & 2010 & 2011 \\
\cline { 3 - 6 } \multicolumn{1}{c}{1} & & \multicolumn{4}{c}{ Ranking position } \\
\cline { 3 - 6 } & & 3 & 4 & 5 & 6 \\
\hline Nemiroff & Production of alcohol & 1 & 1 & 1 & 1 \\
\hline Obolon & Production of beer & 3 & 3 & 2 & 2 \\
\hline Chernihivske & Production of beer & 5 & 5 & 3 & 3 \\
\hline Morshynska & Production of soft drinks & - & - & 29 & 5 \\
\hline Sandora & Production of soft drinks & 6 & 9 & 7 & 6 \\
\hline Khortytsya & Production of alcohol & 2 & 2 & 4 & 7 \\
\hline Roshen & Confectionery & 17 & 13 & 6 & 8 \\
\hline Torchyn & Fruit and vegetable products & 25 & 12 & 11 & 10 \\
\hline Slavutych & Production of beer & 8 & 6 & 8 & 11 \\
\hline Chumak & Fruit and vegetable products & 11 & 10 & 13 & 12 \\
\hline Mivina & Bakery & & & 12 & 13 \\
\hline Korona & Confectionery & 27 & 16 & 14 & 14 \\
\hline Prime & Production of alcohol & 26 & 21 & 21 & 15 \\
\hline Nasha ryaba & Meat & 41 & 23 & 17 & 16 \\
\hline Celsiy & Production of alcohol & - & - & 20 & 17 \\
\hline Veres & Fruit and vegetable products & 12 & 18 & 16 & 18 \\
\hline Nash sok & Production of soft drinks & - & - & - & 19 \\
\hline Oleyna & Oil and fat & 15 & 14 & 18 & 20 \\
\hline Svitoch & Confectionery & 29 & 17 & 19 & 24 \\
\hline
\end{tabular}

Source: prepared on the basis of Ukrbrand's data. 
The data above allows to present a detailed analysis of the results of research on the evaluation of brand by Ukrainian agencies.

According to the ranking of the 100 most expensive UkrBrand national brands of 2011, 58 representatives of the food industry were among the leading brands in Ukraine, which constitutes 5 less than the previous year. Information on the presence of the food industry brands in the rating for 2007-2011 is given in Table 4.

It should also be noted that a group of food brands was the most numerous in the results of the calculations in 2011, and made up to 58\% of ranking leaders. However, compared to 2010 it suffered a 5\% loss, though the industry kept the leading position among other industries.

Table 4. Value of leading brands - producers of food products and beverages rated by UkrBrand, million USD

\begin{tabular}{lccccc}
\hline \multirow{2}{*}{ Brand } & \multicolumn{5}{c}{ Years } \\
\cline { 2 - 6 } \multicolumn{1}{c}{1} & 2007 & 2008 & 2009 & 2010 & 2011 \\
\hline Nemiroff & 2 & 3 & 4 & 5 & 6 \\
\hline Obolon & 266,0 & 302,5 & 325,0 & 404,0 & 460,0 \\
\hline Chernihivske & 242,0 & 272,8 & 280,0 & 322,0 & 353,0 \\
\hline Morshynska & 137,0 & 162,5 & 195,0 & 274,0 & 248,0 \\
\hline Sandora & - & - & - & 46,8 & 212,0 \\
\hline Khortysya & 38,6 & 128,6 & 106,0 & 155,0 & 189,5 \\
\hline Roshen & 315,0 & 285,0 & 290,0 & 197,2 & 167,0 \\
\hline Torchyn & 32,0 & 58,6 & 56,0 & 167,0 & 162,0 \\
\hline Slavutych & 36,4 & 39,6 & 68,6 & 112,0 & 132,0 \\
\hline Chumak & 106,3 & 108,5 & 135,0 & 149,0 & 119,5 \\
\hline Mivina & 72,8 & 73,0 & 90,0 & 102,5 & 106,0 \\
\hline Corona & & & & 105,5 & 103,0 \\
\hline Prime & 42,4 & 38,2 & 51,4 & 98,0 & 100,0 \\
\hline Nasha Ryaba & - & 39,1 & 43,7 & 66,2 & 98,5 \\
\hline Tselsiy & 25,5 & 21,8 & 42,5 & 77,0 & 95,0 \\
\hline Veres & 41,5 & 68,6 & 47,8 & 80,5 & 86,4 \\
\hline Nash Sok & - & - & - & - & 79,0 \\
\hline Oleyna & 41,7 & 61,4 & 52,8 & 76,5 & 77,7 \\
\hline Svitoch & 38,2 & 35,4 & 48,6 & 72,0 & 68,2 \\
\hline
\end{tabular}

Source: prepared by the author on the base of Ukrbrand's data.

At the same time it is necessary to emphasize the changes in the value of brands. According to the results of an evaluation made in 2011 the total value of brands of food industry amounted to $31,577.973 \mathrm{mln}$ UA hryvnyas (Table 5), which is 713.569 million more than in 2010.

According to the rating, and author's studies of the Ukrainian market, the food industry seems to be the leader in terms of the number of brands on the market. Attention needs to be paid to the analysis of the features of specific food industry brands (Table 5).

In 2010 the production of alcoholic beverages was the leader of the quantitative analysis: 22 brands were included in the top 100 brands in Ukraine; the second place went to the dairy industry - with 11 brands in the leaderboard; production of soft drinks held the third position represented by 8 brands; brewing and confectionery industry with 5 brands occupied the fourth and fifth position; sixth result in the amount of 4 brands belonged to tinned 
vegetables and meat processing industry, providing 2 brands each. The next position is taken by fat and oil, and the list is completed by baking industry and the production of chips, with 1 rating member each.

Table 5. Quantitative structure of brands belonging to enterprises of food industry

\begin{tabular}{lcccccccccc}
\hline \multirow{1}{*}{ Branch } & \multicolumn{2}{c}{2007} & \multicolumn{2}{c}{2008} & \multicolumn{2}{c}{2009} & \multicolumn{2}{c}{2010} & \multicolumn{2}{c}{2011} \\
\cline { 2 - 12 } & Units & $\%$ & Units & $\%$ & Units & $\%$ & Units & $\%$ & Units & $\%$ \\
\hline $\begin{array}{l}\text { Production of } \\
\text { alcohol }\end{array}$ & 5 & 20 & 6 & 22,22 & 7 & 23,33 & 22 & 34,92 & 18 & 31,03 \\
\hline Brewing & 5 & 20 & 4 & 14,81 & 3 & 10 & 5 & 7,94 & 7 & 12,07 \\
\hline $\begin{array}{l}\text { Production of soft } \\
\text { drinks }\end{array}$ & 5 & 20 & 6 & 22,22 & 6 & 20 & 8 & 12,7 & 9 & 15,52 \\
\hline Confectionery & 3 & 12 & 3 & 11,11 & 4 & 13,33 & 5 & 7,94 & 7 & 12,07 \\
\hline Oil and fat & 1 & 4 & 1 & 3,7 & 2 & 6,67 & 2 & 3,17 & 1 & 1,72 \\
\hline Meat & 1 & 4 & 1 & 3,7 & 2 & 6,67 & 4 & 6,35 & 2 & 3,45 \\
\hline Milk & 1 & 4 & 2 & 7,41 & 2 & 6,67 & 11 & 17,46 & 7 & 12,07 \\
\hline $\begin{array}{l}\text { Fruit and vegetable } \\
\text { products }\end{array}$ & 3 & 12 & 3 & 11,11 & 3 & 10 & 4 & 6,35 & 5 & 8,62 \\
\hline Bakery & - & - & - & - & - & - & 1 & 1,59 & 1 & 1,72 \\
\hline Production of chips & 1 & 4 & 1 & 3,7 & 1 & 3,33 & 1 & 1,59 & 1 & 1,72 \\
\hline Food in general & 25 & 100 & 27 & 100 & 30 & 100 & 63 & 100 & 58 & 100 \\
\hline
\end{tabular}

Source: calculated on the base of Ukrbrand.

In 2011 the leader of the quantitative analysis was the production of alcoholic drinks, although the number of participants in the rating of the best brands had been reduced from 22 to 18 brands, followed by the second position of production of soft drinks - 9 brands in the leaderboard, the following third position was divided between the dairy, brewing and confectionery industry, providing 7 brands each. The next position in the rating was held by tinned vegetables ( 5 brands), baking industry and the production of chips (each with 1 rating member) completed the list.

It should also be noted that the quantitative measure of the presence of food brands in the ranking of 2011 (compared to 2010) decreased by 5 members. Brewing and confectionery industry demonstrated a quantitative increase of their presence by two positions; the production of soft drinks and tinned vegetables improved the quantitative results by one brand each. The production of alcoholic drinks and dairy products lost 4 brands; meat processing industry lost 2 brands.

Over the studied period the changes occurred in the value of brands (Table 6). Thus, the value of brands of alcoholic beverages, oil-fat, meat and dairy industries increased from 2007 to 2010, and decreased in 2011.

However, the results of 2011 showed that the total value of brands, compared to 2007, increased: in the confectionery industry by 5.48 times, the production of alcoholic beverages by 2.16 times, 2.23 times in the brewing, production of soft drinks by 5.28 times; oil and fat by 2.7 times, 6.54 times in the meat industry; milk - by 6.10 times, tinned vegetables products - 3.39 times, production of chips - 3.39 times; food in general - 3.02 times. Consequently, total cost of meat and dairy industries demonstrated the biggest growth.

Leading positions during the period were covered by the production of alcoholic beverages with a share of $42.1 \%$ in 2007 to $29.9 \%$ in 2011. The second highest proportion in the overall cost of food brands was taken by breweries with negative dynamics: in 2007 $27.8 \%$, in $2011-20.5 \%$. 
Table 6. Structure of brand value of food industry businesses

\begin{tabular}{|c|c|c|c|c|c|c|c|c|c|c|}
\hline \multirow{3}{*}{ Branch } & \multicolumn{10}{|c|}{ Years } \\
\hline & \multicolumn{2}{|c|}{2007} & \multicolumn{2}{|c|}{2008} & \multicolumn{2}{|c|}{2009} & \multicolumn{2}{|c|}{2010} & \multicolumn{2}{|c|}{2011} \\
\hline & $\begin{array}{l}\text { Mln UA } \\
\text { hryvnya }\end{array}$ & $\%$ & $\begin{array}{l}\text { Mln UA } \\
\text { hryvnya }\end{array}$ & $\%$ & $\begin{array}{l}\text { Mln UA } \\
\text { hryvnya }\end{array}$ & $\%$ & $\begin{array}{l}\text { Mln UA } \\
\text { hryvnya }\end{array}$ & $\%$ & $\begin{array}{l}\text { Mln UA } \\
\text { hryvnya }\end{array}$ & $\%$ \\
\hline $\begin{array}{l}\text { Production of } \\
\text { alcohol }\end{array}$ & 4385,7 & 42,04 & 4124,30 & 36,31 & 6416,62 & 35,21 & 10323,58 & 33,45 & 9457,99 & 29,95 \\
\hline Brewing & 2901,25 & 27,81 & 2971,75 & 26,16 & 4751,9 & 26,08 & 6432,98 & 20,84 & 6468,45 & 20,48 \\
\hline $\begin{array}{l}\text { Production of } \\
\text { soft drinks }\end{array}$ & 1043,35 & 10 & 1752,80 & 15,43 & 2488,12 & 13,65 & 3280,01 & 10,63 & 5512,05 & 17,46 \\
\hline Confectionary & 619,3 & 5,94 & 696,69 & 6,13 & 1328,19 & 7,29 & 3309,39 & 10,72 & 3396,01 & 10,75 \\
\hline Oil and fat & 229,35 & 2,2 & 323,57 & 2,85 & 512,58 & 2,81 & 726,51 & 2,35 & 619,26 & 1,96 \\
\hline Meat & 140,25 & 1,34 & 114,88 & 1,01 & 454,15 & 2,49 & 1158,44 & 3,75 & 916,55 & 2,9 \\
\hline Dairy & 182,6 & 1,75 & 269,29 & 2,37 & 363,79 & 2,0 & 1904,80 & 6,17 & 1111,01 & 3,52 \\
\hline $\begin{array}{l}\text { Fruit and } \\
\text { vegetable } \\
\text { products }\end{array}$ & 828,85 & 7,95 & 954,92 & 8,41 & 1607,85 & 8,82 & 2451,07 & 7,94 & 2807,03 & 8,89 \\
\hline Bakery & - & - & - & - & - & - & 837,67 & 2,71 & 820,91 & 2,6 \\
\hline $\begin{array}{l}\text { Production of } \\
\text { chips }\end{array}$ & 101,2 & 0,97 & 151,77 & 1,34 & 299,915 & 1,65 & 439,87 & 1,43 & 468,63 & 1,48 \\
\hline $\begin{array}{l}\text { Food in } \\
\text { general }\end{array}$ & 10431,85 & 100 & 11360,01 & 100 & 18223,14 & 100 & 30864,36 & 100 & 31577,93 & 100 \\
\hline
\end{tabular}

Source: calculated on the base of the Ukrbrand's data.

The third position is occupied by brands-producers of soft drinks, whose value share in 2011 reached $17.4 \%$, that is $7.4 \%$ more than at the beginning of the analysis.

Fourth place was taken by brands owned by confectionery companies: in $2007-5.9 \%$, in $2011-10.7 \%$, increase in the share value is characterized by constant, but marginal annual growth. Fifth position was taken by tinned vegetables industry, with the results of $7.9 \%$ in 2007 -and $8.9 \%$ in 2011 . Sixth place belongs to the producers of dairy products: in $2007-$ $1.8 \%$, in $2011-3.6 \%$. The next highest share in the cost of brand was for meat products, brand share of which in 2011 reached $2.9 \%$.

The last three positions, according to 2011, are occupied by the brands of baking industry $(2.6 \%)$, production of fat and oil products $(1.9 \%)$ and chips $(1.6 \%)$, the share of which, interestingly, never exceeded $3.0 \%$ over the period of 2007-2011. The calculations of average brand value of domestic food industry were the base for summarizing changes in brand value in the years of 2007-2011 (Table 7).

In terms of the average value of 924.065 million UA hryvnyas, in 2011 the most expensive was a brand of beer, second place was taken by a brand of pasta with the value of $820.91 \mathrm{mln}$. UA hryvnyas. This group of brands is represented in the ranking since 2010. The third and fourth ones were oil and fat brands (619.269 mln. UA hryvnyas) and non-alcoholic beverages ( $612.450 \mathrm{mln}$. UA hryvnyas), followed by the brand value of fruits and vegetables (561.407 mln. UA hryvnyas) and alcoholic drinks (525.444 mln. UA hryvnyas), brand value of confectionery was equal to 485.145 million UA hryvnyas, chips brand $-468.636 \mathrm{mln}$. UA hryvnyas, meat brand in average cost 458.275 mln UA hryvnyas.

It should be noted that the lowest average cost of typical brand of dairy industry was 182.6 million UA hryvnyas in 2007 and $158.717 \mathrm{mln}$. UA hryvnyas in 2011 . The average index value of brands in the food industry reached 417.274 million UA hryvnyas in 2007 and $544.447 \mathrm{mln}$. UA hryvnyas in 2011. 
The growth rate of the average value of the brand in certain sectors is presented in Table 7. Brands belonging to none of the analyzed sectors demonstrate sustainable development; a sharp increase is frequently changed to a significant drop in the average value of the brand, which is explained by the factors that formed the price on the food market, and adjustment of ranking structure of the most expensive brands in Ukraine.

In 2011, compared to the previous year, the highest growth was shown by the brand of oil and fat industry (170.5\%) and meat industry (158.4\%), the lowest - the fall in the value of the brewing brand - to $71.85 \%$ and confectionery - to $73,4 \%$.

Table 7. The average value of a brand of the food industry

\begin{tabular}{|c|c|c|c|c|c|c|c|c|c|}
\hline \multirow{2}{*}{ Branches } & \multicolumn{5}{|c|}{$\begin{array}{l}\text { The average value of the brand within years, } \\
\text { mln UA hryvnya }\end{array}$} & \multicolumn{4}{|c|}{$\begin{array}{l}\text { Growth rate, } \% \text { to previous } \\
\text { period }\end{array}$} \\
\hline & 2007 & 2008 & 2009 & 2010 & 2011 & 2008 & 2009 & 2010 & 2011 \\
\hline Brewing & 580,25 & 742,938 & 1583,97 & 1286,598 & 924,065 & 128,0 & 213,3 & 81,2 & 71,85 \\
\hline Bakery & - & - & - & 837,67 & 820,91 & - & - & - & 98,0 \\
\hline Oil and fat & 229,35 & 323,578 & 256,291 & 363,25 & 619,269 & 141,0 & 79,3 & 141,8 & 170,5 \\
\hline $\begin{array}{l}\text { Production of } \\
\text { soft drinks }\end{array}$ & 208,67 & 292,134 & 414,688 & 410,002 & 612,450 & 140,3 & 141,9 & 98,9 & 149,4 \\
\hline $\begin{array}{l}\text { Fruit and } \\
\text { vegetable } \\
\text { products }\end{array}$ & 276,28 & 318,307 & 535,952 & 612,77 & 561,407 & 115,2 & 168,2 & 114,3 & 91,7 \\
\hline $\begin{array}{l}\text { Production of } \\
\text { alcohol }\end{array}$ & 877,14 & 687,384 & 916,660 & 469,254 & 525,444 & 78,3 & 133,3 & 51,2 & 111,9 \\
\hline Confectionery & 206,43 & 232,231 & 332,049 & 661,878 & 485,145 & 112,62 & 143,1 & 199,3 & 73,4 \\
\hline $\begin{array}{l}\text { Production of } \\
\text { chips }\end{array}$ & 101,2 & 151,776 & 299,915 & 439,876 & 468,636 & 149,5 & 198,0 & 146,8 & 106,6 \\
\hline Meat & 140,25 & 114,886 & 227,08 & 289,612 & 458,275 & 81,4 & 199,1 & 127,3 & 158,4 \\
\hline Dairy & 182,6 & 134,645 & 181,897 & 173,164 & 158,717 & 73,6 & 135,0 & 95,5 & 91,3 \\
\hline Food in general & 417,274 & 420,741 & 607,438 & 489,911 & 544,447 & 100,8 & 144,4 & 80,6 & 111,1 \\
\hline
\end{tabular}

Source: calculated on the basis Ukrbrand's data.

The average cost of food brand, which steadily increased until 2009 (607.438 million), the next year of 2010 decreased by $19.4 \%$ to 489.911 million, and already in 2011 showed an increase of $11 \%$ and amounted to 544.447 million UA hryvnyas.

\section{Conclusions}

The analysis shows the relevance of the study of brands in Ukraine, notes the presence of the impact of global trends on the development of the domestic food industry in general, and brands of food and beverages in particular, being manifested in increased competition on the market for Ukrainian commitment to the consumer. The most expensive among national as well as international brands are the drinks. It is worth noting the positive dynamics of brand value of world leaders and instability indices of Ukrainian brands that are characteristic of some sectors of the food industry. The results are reasonable to use in further development of brands in Ukraine. 


\section{References}

Aaker, D. (2003), Building Strong Brands / Аакер Д. Создание сильных брендов / Пер. с англ. - М.: ИД Гребенщикова, 2003. - 440 с.

Gad, T. (2001), 4D branding. Breaking the corporate code of network economy /Гэд T. 4D Брендинг. Взламывая корпоративныи код сетевой экономики. - СПб.: Стокгольмская школа экономики. $-228 \mathrm{c}$.

Kotler, F. (2008), Marketing basics / Котлер Ф., Армстронг Г., Сондерс Дж., Вонг В. Основы маркетинга. - М.: СПб, К.: Вильямс. -944 с.

Domnin, V. (2004), Branding: new technologies in Russia / Домнин В.Н. Брендинг: новые технологии в России: учеб. пособ. - СПб. - Питер, 2004. - 320 с.

Shafalyuk, A. (2009), Humanistic conception of consumer in marketing / Шафалюк О.К. Гуманістична концепція споживача у маркетингу: моногр. - К.: КНЕУ, 2008. $200 \mathrm{c}$.

Zozulyov, A. (2010), Corporate brand: essence and features / Зозульов О., Григораш М. Корпоративний бренд: сутність та особливості // Маркетинг в Україні. - 2010. - №2. - C.36-42. 